\title{
Court-Appointed Lawyer in the Criminal Trial
}

\author{
Silviu-Ștefan Petriman \\ Master of Science in Criminal Justice, "Dimitrie Cantemir" Christian University of Bucharest, Romania \\ silviupetriman@yahoo.com
}

\begin{abstract}
The article presents a few issues about the importance and necessity of a court-appointed lawyer in the criminal trial. In order to secure the right to defence, if the suspect or defendant has not appointed a lawyer to represent his/her interests, the judicial body has the obligation to take measures in order to appoint a public defender. Therefore, the protection of such rights must be material and objective, not only theoretical and illusory. But the appointment of a lawyer only is not enough to provide effective assistance. The public defender is appointed on written demand of court, justice of peace, preliminary chamber judge, criminal investigation or search body, bar council. The suspect or defendant is not allowed to elect a public defender. If appointed, the public defender has the obligation to provide legal assistance less when there is a conflict of interest between the lawyer or a suspect or defendant. This measure is determined both for consolidating the idea of fair, transparent justice and for securing a fair trial to the individuals criminally accused.
\end{abstract}

KEYWORDS: criminal accusation, fair trial, Lawyer, legal assistance, right to defence

\section{Introduction}

By legal assistance, one understands the service of legal assistance offered by a lawyer, according to art. 150 par. (1) of the Law on legal profession. The persons accused of committing an infraction must be informed related to the accusation, to be able to prepare his/her defence, to enjoy a fair trial, in a state of law. Although not everyone has a financial situation that may allow him/her to hire a lawyer, the state has the obligation to provide for his/her defence in the criminal trial.

\section{Notion of Legal Assistance}

The legal assistance represents, on the one hand, a guarantee of observance of general principles in a criminal trial, and on the other hand, it is an important part of the right to defence. There is no identity between the legal assistance and judicial assistance. The legal assistance is granted on demand of the client, whereas in case of judicial assistance, the lawyer is appointed by the bar, on demand of judicial body. The judicial assistance entails an institutional collaboration between U.N.B.R. (National Union of Romanian Bars) and the Ministry of Justice, the Superior Council of Magistracy, the courts etc. (Dinu 2017, 21).

In this respect, each bar organizes and provides a judicial assistance service, attached to each district court, which is a responsibility of Bar's Council.

The lawyer appointed to provide legal assistance in the criminal trial is protected by law, being subject only to law, the Law on legal profession and Deontological Code. The free legal assistance in the criminal trial is granted if the suspect or defendant has no lawyer and the legal assistance is obligatory. When the lawyer is appointed ex officio, he has no right to receive from the suspect or defendant any amount of money or other awards. The mandate of the lawyer ex officio terminates when the suspect or the defendant hires a lawyer.

The lawyer ex officio has the obligation to study thoroughly the cases assigned to him, to appear on the terms determined by courts and criminal investigation bodies. He has to manifest scrupulosity and professional probity, to file written submissions or meeting notes, when the nature or difficulty of the case entail it. It is not enough a simple appointment of the lawyer ex officio, the judicial bodies have the obligation to make sure that the lawyer has studied the case, has knowledge of the parts of file, and is actually able to provide for an effective defence. The lawyer ex officio cannot refuse to provide legal assistance, but in case of incompatibility of conflict of interests (for instance, he has been witness in the case). 


\section{Obligatory Legal Assistance for the Suspect or Defendant}

According to the Code of Criminal Procedure, during the entire criminal trial, the legal assistance of suspect or defendant is obligatory in the following situations:

a) The suspect or defendant is underage;

b) The suspect or defendant is hospitalised in an educative centre or centre of detention;

c) The suspect or defendant is in remand custody or house arrest, even in another case. If remand in custody has been ordered in default, the legal assistance will be obligatory as of the date of deprivation of freedom of defendant and not between the date of the issue of remand in custody mandate and the date of enforcement of it (it is necessary the prior hearing of the suspect or defendant in the presence of the lawyer)

d) it has been ordered a safety measure of medical hospitalisation, even in another case, against the suspect or the defendant;

e) if the criminal investigation body, the justice of peace or the indictment division of court or the court considers that the suspect or defendant is not able to provide for his/her own defence. Under certain complex situations, specialised assistance is needed (by lawyer), since the right to defence exercised personally may be affected.

\section{Legal Assistance of Defendant during Different Trial Stages}

The obligation of legal assistance of defendant appears as well during different trial stages, such as in case of taking and extending the procedure of involuntary medical hospitalisation; on the occasion of settlement of the appeal against the judgement passed by the justice of peace in first court;

On the occasion of debating the proposal of taking the measure of remand in custody or house arrest against the defendant not detained, the judicial assistance is obligatory as well as during the procedure of settlement of the appeal against the judgements passed related to the preventive measure by the justice of peace or the indictment division of court. The legal assistance is also obligatory during the judicial control or judicial control on bail; in the procedures of debates ex officio of the legality and merits of preventive measures; in the procedures related to the debate of termination as of right of preventive measures; in the procedure during the criminal investigation, related to concluding an agreement of acceptance of guilt; in the procedures of taking, confirmation, substitution or termination of a provisional procedural measure of obligation to medical treatment or medical hospitalisation, organised before the indictment division of court pursuant to passing a judgement of no trial (Udroiu 2018, 908-910).

The legal assistance is also obligatory during the directions hearing, as well as during the trial, in the cases when the law stipulates for the infraction committed the life detention or imprisonment for more than 5 years. By the penalty stipulated by law, we consider the penalty stipulated by the indictment rule, without considering the cases of reduction or increase of penalty.

The legal assistance in this situation is obligatory both for the defendant natural person and for the defendant legal person. In this respect, the High Court of Cassation and Justice by judgement no 21/HP/2016 stated "that in the interpretation and enforcement of the disposals of art. 90, lett. c) Code of Criminal Procedure, during the directions hearing and trial, in the cases when the law stipulates for the infraction committed life detention or imprisonment for more than 5 years, the legal assistance is obligatory for the defendant legal person, according to the disposals of art. 187 Criminal Code".

If the court considers that it is necessary to change the legal classification (in terms of art. $386 \mathrm{CPP}$ ) and orders it ,and according to the new legal classification of offence, the penalty stipulated by law is imprisonment more than 5 years, the legal assistance becomes obligatory as of the date the court passes the measure.

During the trial, the obligatory nature of legal assistance entails a defence during the entire trial and all trial hearings.

For obligatory legal assistance, if the lawyer appointed by the suspect or defendant, is absent without reasonable justification, does not provide for substitution or refuses without reason to exercise the right to defence, although it has been provided for the exercise of all procedural rights, 
the judicial body takes steps to appoint a lawyer ex officio, to substitute him, providing the latter a reasonable term and the facilities necessary for an effective defence. This will be recorded in a protocol, or if any in the judgment.

\section{Legal Assistance of Plaintiff, Responsible Party in Civil Suit and Aggrieved Party}

In the case of an aggrieved party, plaintiff and responsible party in civil suit, the legal assistance is in principle facultative, however, there are some exceptions. Therefore, if the aggrieved party or the plaintiff is a person lacking legal competence or with restricted legal competence, the legal assistance is obligatory. This is not applicable to the responsible party in civil suit.

Another situation of obligatory legal assistance is when the judicial body considers that the aggrieved person, the plaintiff or the responsible party in civil suit is unable to provide for its own defence.

A special case of obligatory legal assistance of aggrieved party is when it is the victim of the offence of human trafficking. In this case, art. 44 par. (1) of Law no 678/2001 stipulates that it will be provided obligatory legal assistance to be able to exercise its rights in the criminal procedures stipulated by law, during all phases of criminal trial, and to sustain its petitions and civil claims against the persons who have committed the infractions stipulated by this law, in which they are involved.

According to the Code of Criminal Procedure during the trial, the aggrieved party and the parties are entitled to only one hearing to appoint a lawyer and prepare the defence. If the aggrieved party or the parties fail to appoint a lawyer within the term granted by court, the trial shall continue, the legal assistance being provided ex officio for the cases of obligatory legal assistance.

In the criminal trial, the lawyer ex officio may be only a lawyer registered in the table of the Bar part of the National Union of Bars in Romania. "The legal assistance granted in the criminal trial to a defendant or accused, by a lawyer not acquiring the status of lawyer in terms of Law no 51/1995 is equivalent to lack of defence (Decision no 27/2007, ICCJ-RIL, published in the Official Gazette no 772 dated $14^{\text {th }}$ November 2007).

If the breach of the disposals related to obligatory legal assistance during the trial in first court (not if the lack of defence has targeted the criminal investigation or the directions hearing) is determined by the court of appeal, the case will be remanded for retrial to first court. The breach during the trial of the disposals of obligatory legal assistance of the defendant may be claimed by appeal for annulment (Neagu, Damaschin and Iugan 2016, 85).

An important aspect, in the lawyer-client relationship, is that of respecting professional secrecy. The Right of an accused to communicate with the lawyer or in the absence of any other person is part of the basic requirements of a fair trial.

Court of Justice of the European Union in AM\&S v Commission: Keeping confidentiality in connection with certain communications between the lawyer and the client constitutes a general principle of law, common to the laws of all Member States and therefore a right fundamentally protected by Community legislation.

It is necessary to examine whether the obligation incumbent on a lawyer acting in the exercise of his professional duties to cooperate with the competent authorities in the field of combating money laundering, within the meaning of article 6 alin. (1) of Directive 91/308, and to inform these authorities of their own initiative of any fact which may indicate a money laundering, taking into account the limitations of the above obligation mentioned in article 2a (5) and article 6 alin. (3) of those Directives, constitutes a breach of the right to a fair process guaranteed by art. 6 of the Convention and by art. 6 par. (2) TEU. Article 6 alin. (3) par. 2 of Directive 91/308 may be subject to several interpretations, so that the precise stretching of the information and cooperation obligations incumbent on lawyers is not unambiguous. In this regard, according to a constant caselaw, when a text of derived Community law can receive more interpretations, it must prevail over that interpretation which determines the conformity of the provisions with the EU Treaty rather than that which leads to the finding of its incompatibility with the EU Treaty. 
Indeed, Member States do not only have the obligation to interpret their national law in a manner consistent with Community law, but also to ensure that they are not based on an interpretation of a text of secondary law that would conflict with the rights Fundamental rights protected by the Community legal order or other general principles of Community law (Lindqvist Case, Decision of 6.11.2003 par. 87 in the Code of Criminal Procedure annotated (Neagu, Damaschin and Iugan 2018, 181).

\section{Conclusions}

For the observance of the right to a fair trial, it is necessary, among others, the guarantee of the right to defence of the person accused. In order to assure such right, it is necessary that the suspect or defendant, who has no financial means to hire a lawyer, to be provided by state specialised defence (by lawyer) so as any individual committing an infraction is held criminally liable according to his/her guilt.

It should be noted that article 6 of the D.E.O. Convention on the right to a fair process is an incident from the time of a criminal prosecution, and from this moment the accused person must have a lawyer in order to prepare the defense, because the defendant was in a position of vulnerability. This way, by the presence of the lawyer, he assures the defendant that he will not contribute to his own indictment.

\section{References}

Case C-305/05 Ordre des barreaux francophones et germanophone, Ordre francais des avocats du barreau de Bruxelles, Ordre des barreau flamands, Ordre neerlandais des avocats du barreaux de Bruxelles c. Conseil des ministers.

Decision no 27/2007, ÎCCJ-RIL, published in the Official Gazette no 772 dated $14^{\text {th }}$ November 2007.

Dinu, Claudiu Constantin. 2017. Fișe privind organizarea și exercitarea profesiei de avocat. (File on the organisation and exercise of legal profession). Bucharest: Hamangiu Publishing House.

Law no 135/2010 - Code of Criminal Procedure. Published in Official Gazette no 486 of July 15, 2010.

Law no 286/2009 - Romanian Criminal Code. Published in Official Gazette no 510 of July 24, 2009.

Law no 51/1995 on the organization and pursuit of the lawyer's profession. Published in Official Gazette no 116 of June 9, 1995, Republished in Official Gazette no 440 of May 24, 2018.

Neagu, I., Damaschin M., Iugan A.V. 2016. Criminal Law Procedure. General Part. Seminar workbook. Bucharest: Universul Juridic Publishing House.

Neagu, I., Damaschin M., Iugan A.V. 2018. Code of Criminal Procedure. Adnotated. General Part. Bucharest: Universul Juridic Publishing House.

Udroiu, M. 2018. Code of Criminal Procedure General Part. Bucharest: C.H. Beck Publishing House. 